\title{
Exploitation of combining ability and heterosis for development of maize hybrids for tarai region of Uttarakhand
}

\author{
Manjeet Kumar*, S. S. Verma, Meenakshi Uniyal, Anupam Barh and N.K. Singh
}

Department of Genetics and Plant Breeding, G. B. Pant University of Agriculture and Technology, Pantnagar263145 (Uttarakhand), INDIA

*Corresponding author. E-mail: manjeetbhu615@gmail.com

Received: December 21, 2015; Revised received: June 21, 2016; Accepted: August 14, 2016

\begin{abstract}
The present investigation was carried out with fifty six genotypes involving 10 parents, their $45 F_{1 s}$ hybrids and one check hybrid in tarai region of Uttarakhand. The presence of more amount of variance due to SCA effects than GCA effects in our experimental material indicated that heterosis breeding is better choice. The good general combiners were $P_{1}, P_{3}$ and $P_{4}$ for ear length; $P_{8}$ for ear diameter; $P_{5}$ and $P_{8}$ for number of kernel rows per ear; $P_{1}$ and $\mathrm{P}_{4}$ for number of kernels per row, $\mathrm{P}_{8}$ and $\mathrm{P}_{9}$ for100-kernel weight and $\mathrm{P}_{5}$ for grain yield, which can be utilized directly or indirectly in breeding programme. The best eight specific combiners for grain yield were $P_{1} \times P_{8}, P_{4} \times P_{10}, P_{7} \times P_{8}$, $P_{5} \times P_{8}, P_{5} \times P_{9}, P_{4} \times P_{9}, P_{1} \times P_{2}$ and $P_{5} \times P_{10}$ involving average $x$ average, good $x$ average, good $x$ poor and average $x$ poor parental combinations of generalcombining ability indicating the presence of non-additive gene action. The nine crosses, $\mathrm{P}_{1} \times \mathrm{P}_{2}, \mathrm{P}_{1} \times \mathrm{P}_{5}, \mathrm{P}_{1} \times \mathrm{P}_{8}, \mathrm{P}_{4} \times \mathrm{P}_{9}, \mathrm{P}_{4} \times \mathrm{P}_{10}, \mathrm{P}_{5} \times \mathrm{P}_{8}, \mathrm{P}_{5} \times \mathrm{P}_{9}, \mathrm{P}_{5} \times \mathrm{P}_{10}$ and $\mathrm{P}_{7} \times \mathrm{P}_{8}$ had positive significant per cent heterosis for grain yield, and crosses namely $P_{1} \times P_{4}, P_{1} \times P_{5}$ and $P_{1} \times P_{8}$ for ear length; $P_{1} \times P_{3}$ and $P_{1} \times P_{5}$ for number of kernels per row and $\mathrm{P}_{1} \times \mathrm{P}_{8}$ and $\mathrm{P}_{9} \times \mathrm{P}_{10}$ for 100 -kernel weight were having positive significant per cent heterosis at $1 \%$ and/or $5 \%$ level of significance for respective traits. The crosses, $\mathrm{P}_{1} \times \mathrm{P}_{2}, \mathrm{P}_{1} \times \mathrm{P}_{8}, \mathrm{P}_{4} \times \mathrm{P}_{9}$ and $\mathrm{P}_{7} \times \mathrm{P}_{8}$ manifested high SCA effects along with excellent standard heterosis and per se performance for grain yield and also for most of the studied characters, therefore, classified as potential hybrids.
\end{abstract}

Keywords: Combining ability, Maize, Per se performance, Standard heterosis

\section{INTRODUCTION}

Maize (Zea mays L.) has emerged as world's leading crop among the cereals with highest production and productivity (Kumar et al., 2015). In India, maize is third important food crop after wheat and rice and its production has been recorded about 24.35 MT from 9.4 mha area with average productivity of $2.5 \mathrm{t} \mathrm{ha}^{-1}$ in 2013-14, which is almost half to the world average (AICRP on Maize, 2015).Due to maize being allogamous crop species, maintenance of heterozygosity is utmost important to suppress the undesirable effect of recessive alleles, therefore, grain productivity enhancement needs better exploitation of heterosis utilizing additive and non-additive gene actions. To develop good economically viable maize hybrid, information on the heterotic patterns and combining ability among maize germplasm is essential to maximize the effectiveness of hybrid development (Amiruzzaman et al., 2010). Combining ability analysis elucidates the combining ability of parents and their crosses and also nature and magnitude of various types of gene actions involved in the expression of quantitative characters. Therefore, it is a powerful tool in the identification of best combiners and breeding strategies to be adopted either heterosis breeding or recombinant breeding for the accumulation of desirable genes. Thus study was performed with the ob- jective of identification of desirable parents, crosses and breeding strategies to be adopted on the basis of various types of gene actions and combining ability of parents and crosses.

\section{MATERIALS AND METHODS}

The present investigation was undertaken with ten parental lines namely CML $226\left(\mathrm{P}_{1}\right)$, POP31 $\left(\mathrm{P}_{2}\right)$, YHP-B $\left(\mathrm{P}_{3}\right)$, POP $31\left(\mathrm{P}_{4}\right)$, Pob $446\left(\mathrm{P}_{5}\right)$, POB $45\left(\mathrm{P}_{6}\right)$, Tarun $\left(\mathrm{P}_{7}\right), \mathrm{POB}$ $45\left(\mathrm{P}_{8}\right)$, PHPA $\left(\mathrm{P}_{9}\right)$, Pob $445\left(\mathrm{P}_{10}\right)$, which were crossed in half diallel fashion(excluding reciprocals) to develop forty five $\mathrm{F}_{1} \mathrm{~s}$ hybrids during rabi 2012-13, at N. E. Borlaug Crop Research Center, Pantnagar, Uttarakhand. These parental lines along with $45 \mathrm{~F}_{1}$ s hybrids and one commercial check hybrid, (PSM 1) were evaluated in randomized block design with three replications in plot size of $6.00 \mathrm{~m}^{2}$ in the following kharif 2013, at same research farm. The data was recorded on grain yield $(\mathrm{YH})$ and important yield attributing traits namely ear length (EL), ear diameter (ED), number of kernel rows/ear (NKR/E), number of kernels/row (NK/R) and 100-kernel weight (100-SW). Standard heterosis against the commercial check hybrid was calculated and tested as per methods given by Singh and Singh (1994), and significance of heterosis was tested using $\mathrm{t}-$ test at $1 \%$ and $5 \%$ level of significance. The combining ability analysis was per- 
formed with method 2 and Model I of Griffing (1956) using AGD-R software, CIMMYT.

\section{RESULTS AND DISCUSSION}

The analysis of variance for combining ability revealed that variance due to GCA and SCA were significant for all above mentioned characters indicating that both type of gene actions namely additive and non- additive gene actions are important for expression of characters (Table 1). In which GCA can be exploited for the improvement of parental inbred lines through fixation of deesirable genes acting in additive fashion, while SCA based on non-additive gene actions through development of effective hybrids. Rokadia and Kaushik (2005); Amiruzzaman et al.(2010) and Aminu et al. (2014) also observed the significant values of both GCA and SCA effects showing the presence of addi- tive and non-additive gene actions for yield and yield attributing traits. The present experimental material is also having the significant levels of both types of gene action which might be utilized for crop improvement programme. The ratio $0^{2} \mathrm{GCA}$ to $0^{2} \mathrm{SCA}$ lesser than unity for all the studied characters were recorded which indicated the presence of more amount of nonadditive than additive type of gene action (Table 1). Therefore, idea of opting for maintaining heterozygosity i.e. heterosis breeding for grain yield and yield contributing characters is recommended. Alamine et al. (2003); Kambe et al. (2013) and Aminu et al. (2014) also observed the less than unity ratio between $0^{2} \mathrm{GCA}$ to $0^{2} \mathrm{SCA}$ for yield and yield attributing traits, and also recommended the heterosis breeding for crop improvement programme, but Alam et al. (2008) reported the significant role of additive gene action for number of

Table 1. Analysis of variance for combining ability and variance effects with respect to yield and yield attributing traits of maize .

\begin{tabular}{lccccccc}
\hline Source of variation & $\mathbf{d f}$ & $\mathbf{E L}$ & $\mathbf{E D}$ & $\mathbf{N K R} / \mathbf{E}$ & $\mathbf{N K} / \mathbf{R}$ & $\mathbf{1 0 0 - S W}$ & $\mathbf{Y H}$ \\
\hline Due to GCA & 9 & $9.77^{* *}$ & $0.27^{* *}$ & $3.73^{* *}$ & $39.15^{* *}$ & $14.83^{* *}$ & $321.43^{* *}$ \\
Due to SCA & 45 & $13.03^{* *}$ & $0.33^{* *}$ & $2.28^{* *}$ & $76.80^{* *}$ & $20.21^{* *}$ & $727.13^{* *}$ \\
Error & 108 & 0.96 & 0.09 & 0.49 & 8.50 & 2.25 & 82.09 \\
$\boldsymbol{\sigma}^{\mathbf{2}} \mathbf{G C A}$ & & 0.240 & 0.010 & 0.090 & 0.851 & 0.350 & 6.648 \\
$\boldsymbol{\sigma}^{2} \mathbf{S C A}$ & & 4.020 & 0.080 & 0.595 & 22.767 & 5.985 & 215.014 \\
$\boldsymbol{\sigma}^{\mathbf{2}} \mathbf{G C A} / \boldsymbol{\sigma}^{\mathbf{2}} \mathbf{S C A}$ & & 0.060 & 0.060 & 0.151 & 0.037 & 0.058 & 0.031 \\
\hline
\end{tabular}

*, ** Significant at $5 \%$ and $1 \%$ probability levels, respectively; GCA- General combining ability; SCA- Specific combining ability; $\sigma^{2}$ GCA- variance due to GCA; $\sigma^{2}$ SCA- variance due to SCA; EL-Ear Length; ED-Ear Diameter; NKR/E- No. of Kernel Rows per Ear; NK/R- No. of Kernels per Ror; 100-SW-100 Seed Weight; YH- Yield per Hectare

Table 2. General combining ability effects (GCA) and per se performance of parental lines with respect to yield and yield attributing traits of maize.

\begin{tabular}{|c|c|c|c|c|c|c|c|c|c|c|c|c|c|}
\hline \multirow[b]{2}{*}{ S. N. } & \multirow[b]{2}{*}{ Genotype } & \multicolumn{2}{|c|}{ EL } & \multicolumn{2}{|r|}{ ED } & \multicolumn{2}{|c|}{ NKR/E } & \multicolumn{2}{|c|}{ NK/R } & \multicolumn{2}{|c|}{ 100-SW } & \multicolumn{2}{|c|}{ YH } \\
\hline & & GCA & $\begin{array}{c}\text { Per se } \\
\text { perform- } \\
\text { ance }\end{array}$ & GCA & $\begin{array}{c}\text { Per se } \\
\text { perform- } \\
\text { ance }\end{array}$ & GCA & $\begin{array}{c}\text { Per se } \\
\text { perform- } \\
\text { ance }\end{array}$ & GCA & $\begin{array}{c}\text { Per se } \\
\text { perform- } \\
\text { ance }\end{array}$ & GCA & $\begin{array}{c}\text { Perse } \\
\text { perform- } \\
\text { ance }\end{array}$ & GCA & $\begin{array}{c}\text { Per se } \\
\text { perform- } \\
\text { ance }\end{array}$ \\
\hline 1. & $\mathrm{P}_{1}$ & $0.95 * *$ & 13.25 & 0.02 & 3.47 & -0.10 & 12.56 & $1.81 * *$ & 25.89 & 0.24 & 18.52 & 2.55 & 23.34 \\
\hline 2. & $\mathrm{P}_{2}$ & $-0.66 * *$ & $10.08-$ & $-0.12 *$ & 3.43 & $-0.22 *$ & 11.47 & -0.38 & 25.80 & $-0.69 * *$ & 21.72 & -0.50 & 27.49 \\
\hline 3. & $\mathrm{P}_{3}$ & $0.41 * *$ & 11.67 & -0.05 & 3.51 & $-0.33 * *$ & 11.27 & 0.41 & 22.43 & -0.10 & 25.07 & -2.80 & 23.31 \\
\hline 4. & $\mathrm{P}_{4}$ & $0.59 * *$ & 15.73 & 0.04 & 3.97 & 0.15 & 13.90 & $1.82 * *$ & 35.73 & $-0.88 * *$ & 23.09 & -0.69 & 34.22 \\
\hline 5. & $\mathrm{P}_{5}$ & 0.01 & 12.47 & -0.03 & 3.65 & $0.34 * *$ & 12.30 & -0.21 & 25.22 & -0.25 & 23.02 & $6.03 * *$ & 23.77 \\
\hline 6. & $\mathrm{P}_{6}$ & $-0.44 * *$ & 10.23 & -0.07 & 3.67 & $-0.37 * *$ & 12.29 & -0.87 & 20.22 & -0.31 & 22.46 & -2.27 & 26.89 \\
\hline 7. & $\mathrm{P}_{7}$ & $-0.46 * *$ & 12.63 & 0.06 & 3.93 & 0.13 & 12.50 & -0.43 & 30.67 & -0.33 & 21.96 & -2.16 & 23.95 \\
\hline 8. & $\mathrm{P}_{8}$ & 0.17 & 13.070 & $0.19 * *$ & 3.67 & $0.61 * *$ & 13.60 & -0.24 & 28.97 & $0.86 * *$ & 23.13 & 2.05 & 30.61 \\
\hline 9. & $\mathrm{P}_{9}$ & $-0.31 *$ & 11.43 & 0.01 & 3.27 & 0.10 & 12.67 & $-1.06 *$ & 21.97 & $1.13 * *$ & 26.72 & 1.38 & 27.44 \\
\hline 10. & $\mathrm{P}_{10}$ & -0.27 & 8.43 & -0.06 & 3.07 & $-0.31 * *$ & 10.20 & -0.85 & 17.90 & 0.32 & 20.64 & $-3.60 *$ & 16.60 \\
\hline 11. & S.E. $\left(g_{i}\right)$ & 0.16 & 13.25 & 0.05 & 3.47 & 0.11 & 12.56 & 0.46 & 25.89 & 0.24 & 18.52 & 1.43 & 23.34 \\
\hline 12. & $\mathrm{SE}\left(\mathrm{g}_{\mathrm{i}}-\mathrm{g}_{\mathrm{j}}\right)$ & 0.23 & 10.08 & 0.07 & 3.43 & 0.17 & 11.47 & 0.69 & 25.80 & 0.35 & 21.72 & 2.14 & 27.49 \\
\hline
\end{tabular}

*, ** Significant at $5 \%$ and $1 \%$ probability levels, respectively; GCA- General combining ability; SCA- Specific combining ability; $\sigma^{2}$ GCA- variance due to GCA; $\sigma^{2}$ SCA- variance due to SCA; EL-Ear Length; ED-Ear Diameter; NKR/E- No. of Kernel 
Manjeet Kumar et al. / J. Appl. \& Nat. Sci. 8 (3): 1570 - 1575 (2016)

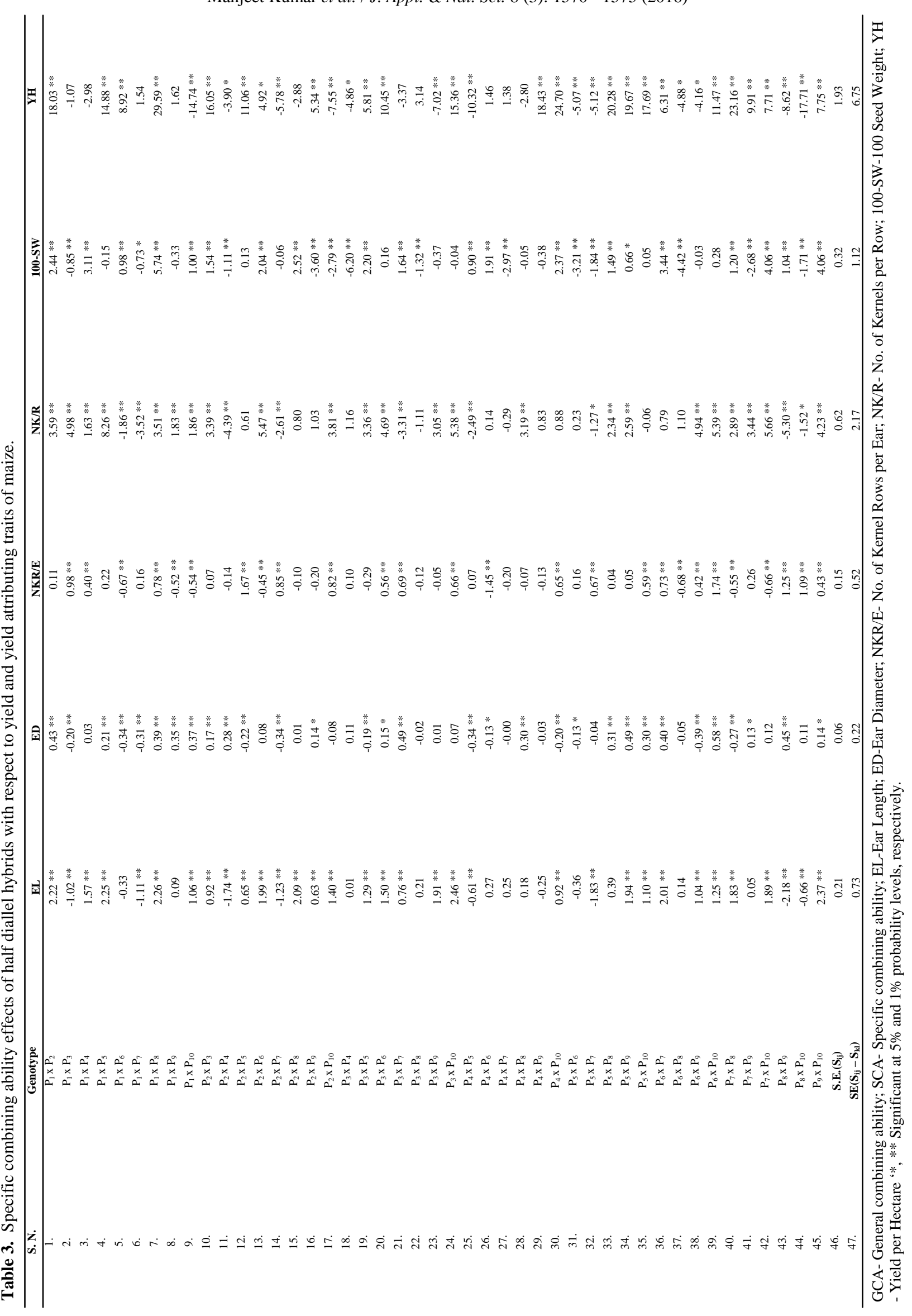




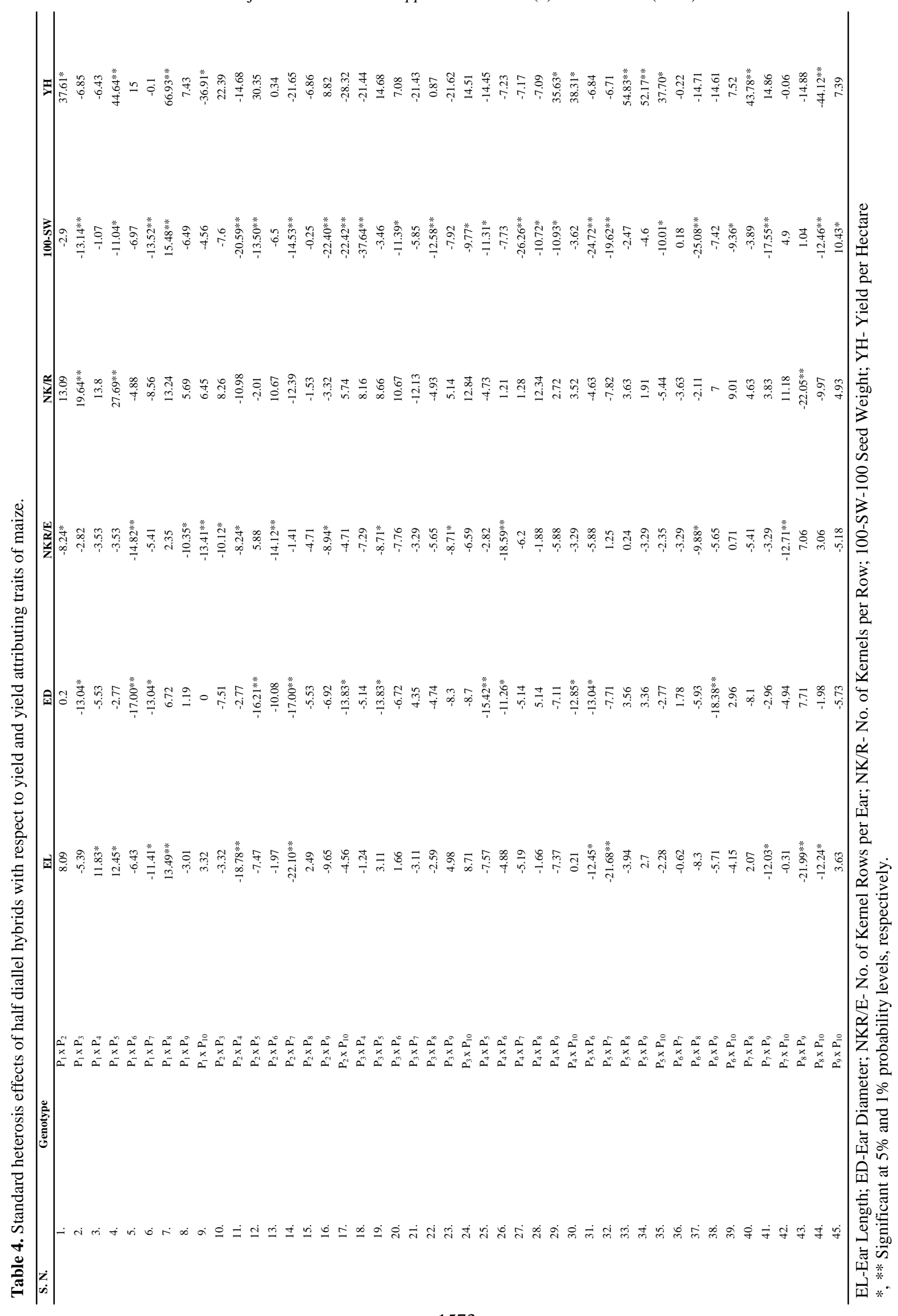


kernels per ear and 100-kernel weight. Therefore, additive gene action of both traits can be fixed through improvement of inbred lines.

General combining ability (GCA) effects: The GCA estimates and per se performance of parental lines are presented in Table 2. In present study, parents with significant positive GCA effects were classified as good general combiner; with non-significant GCA as average combiner and significant negative GCA effects were classified as poor general combiner. The good general combiners for yield attributing traits were $\mathrm{P}_{1}, \mathrm{P}_{3}$ and $\mathrm{P}_{4}$ for ear length; $\mathrm{P}_{8}$ for ear diameter; $\mathrm{P}_{5}$ and $\mathrm{P}_{8}$ for number of kernel rows per ear; $\mathrm{P}_{1}$ and $\mathrm{P}_{4}$ for number of kernels per row and $\mathrm{P}_{8}$ and $\mathrm{P}_{9}$ for100-kernel weight. The parent, $\mathrm{P}_{5}$ was good general combiner for yield along with good general combiner for number of kernel rows per ear and average general combiner for remaining yield attributing traits, but could not be qualified as having potential directly for hybrid breeding programme because of its low per se performance. Some yield attributing traits namely ear length, number of kernel rows per ear, number of kernels per row and 100-kernel weight had somewhat correlations between high per se performance and good GCA effects. Amiruzzaman et al. (2010) also identified the correlation of good general combining ability of grain yield and other yield attributing traits with per se performance of parental genotypes. Therefore, per se performance of parents could be used as useful index for general combining ability.

Specific combining ability (SCA) effects: The SCA estimates of crosses are presented in Table 3. The SCA effects ranged from -2.18 to 2.46 for ear length; -0.39 to 0.58 for ear diameter; -1.45 to 1.74 for number of kernel rows per ear; -5.30 to 8.26 for number of kernels per row; -6.20 to 5.74 for 100 -kernel weight and 17.71 to 29.59 for grain yield. The number of crosses having significant positive SCA effects was 25 for ear length; 19 for ear diameter; 18 for number of kernel rows per ear; 23 for number of kernels per row; 20 for 100-kernel weight and 22 for grain yield. For grain yield best eight specific combiners were $\mathrm{P}_{1} \mathrm{x} \quad \mathrm{P}_{8}$ (25.59), $\mathrm{P}_{4} \times \mathrm{P}_{10}$ (24.70), $\mathrm{P}_{7} \times \mathrm{P}_{8}$ (23.16), $\mathrm{P}_{5} \times \mathrm{P}_{8}$ (20.28), $\mathrm{P}_{5} \mathrm{x} \mathrm{P}_{9}$ (19.67), $\mathrm{P}_{4} \times \mathrm{P}_{9}$ (18.43), $\mathrm{P}_{1} \times \mathrm{P}_{2}$ (18.03) and $\mathrm{P}_{5} \mathrm{x}$ $\mathrm{P}_{10}$ (17.69). The crosses namely $\mathrm{P}_{1} \mathrm{x} \mathrm{P}_{8}$ and $\mathrm{P}_{7} \times \mathrm{P}_{8}$ were also having the positive significant SCA effects for all studied yield attributing traits while other remaining crosses were having the positive significant SCA effects for most of the yield attributing traits in addition to good SCA effect. In contrast to GCA effect (additive gene action), SCA effect are the result of non -additive gene actions (dominance and epistatic interaction). Among these eight best significant positive crosses for grain yield, four $\left(\mathrm{P}_{1} \times \mathrm{P}_{2}, \mathrm{P}_{1} \times \mathrm{P}_{8}, \mathrm{P}_{4} \times \mathrm{P}_{9}\right.$ and $\left.\mathrm{P}_{7} \times \mathrm{P}_{8}\right)$ were having parents with average $\mathrm{x}$ average general combiner; two $\left(\mathrm{P}_{5} \times \mathrm{P}_{8}\right.$ and $\left.\mathrm{P}_{5} \times \mathrm{P}_{9}\right)$ with good $\mathrm{x}$ average general combiner parents; $\mathrm{P}_{5} \mathrm{x} \mathrm{P}_{10}$ with good $\mathrm{x}$ poor parents and $\mathrm{P}_{4} \mathrm{x} \mathrm{P}_{10}$ with average $\mathrm{x}$ poor parents. These parental combinations show the clear role of non -additive gene action in SCA effects. The SCA effects of grain yield and yield attributing traits in maize were also reported by Amiruzzaman et al. (2010); Haddadi et al. (2012); Aminu et al. (2014) and Guerrero et al. (2014), also had given the emphasis on heterosis breeding for exploitation of non-additive gene action for maize improvement program.

Heterosis: The per cent standard heterosis of crosses is presented in Table 4. Per cent standard heterosis was ranged from $-22.10\left(\mathrm{P}_{2} \times \mathrm{P}_{7}\right)$ to $13.49\left(\mathrm{P}_{1} \times \mathrm{P}_{8}\right)$ for ear length; $-18.38\left(\mathrm{P}_{6} \times \mathrm{P}_{9}\right)$ to $7.71\left(\mathrm{P}_{8} \times \mathrm{P}_{9}\right)$ for ear diameter; -18.59 $\left(\mathrm{P}_{4} \times \mathrm{P}_{6}\right)$ to $7.06\left(\mathrm{P}_{8} \times \mathrm{P}_{9}\right)$ for number of kernel rows per ear; $-22.05\left(\mathrm{P}_{8} \times \mathrm{P}_{9}\right)$ to $27.69\left(\mathrm{P}_{1} \times \mathrm{P}_{5}\right)$ for number of kernels per row; $-37.64\left(\mathrm{P}_{3} \times \mathrm{P}_{4}\right)$ to $15.48\left(\mathrm{P}_{1} \times \mathrm{P}_{8}\right)$ for 100-kernel weight and -44.12 $\left(\mathrm{P}_{8} \mathrm{X}\right.$ $\left.\mathrm{P}_{10}\right)$ to $66.93\left(\mathrm{P}_{1} \times \mathrm{P}_{8}\right)$ for grain yield. None of the crosses was having the positive significant per cent standard heterosis for ear diameter and number of kernel rows per ear. Elymyhum (2013) also reported the non-significant genetic difference ultimately significant standard heterosis for ear diameter and number of kernel rows per ear. While, three crosses $\left(\mathrm{P}_{1} \times \mathrm{P}_{4}, \mathrm{P}_{1} \mathrm{x}\right.$ $\mathrm{P}_{5}$ and $\left.\mathrm{P}_{1} \times \mathrm{P}_{8}\right)$ for ear length; two crosses $\left(\mathrm{P}_{1} \times \mathrm{P}_{3}\right.$ and $\left.\mathrm{P}_{1} \times \mathrm{P}_{5}\right)$ for number of kernels per row; two crosses $\left(\mathrm{P}_{1}\right.$ $\mathrm{x} \mathrm{P}_{8}$ and $\left.\mathrm{P}_{9} \times \mathrm{P}_{10}\right)$ for 100-kernel weight and nine crosses $\left(\mathrm{P}_{1} \times \mathrm{P}_{2}, \mathrm{P}_{1} \times \mathrm{P}_{5}, \mathrm{P}_{1} \times \mathrm{P}_{8}, \mathrm{P}_{4} \times \mathrm{P}_{9}, \mathrm{P}_{4} \times \mathrm{P}_{10}, \mathrm{P}_{5} \times \mathrm{P}_{8}\right.$, $\mathrm{P}_{5} \times \mathrm{P}_{9}, \mathrm{P}_{5} \times \mathrm{P}_{10}$ and $\mathrm{P}_{7} \times \mathrm{P}_{8}$ ) for grain yield had positive significant per cent standard heterosis. The magnitude of per cent standard heterosis for grain yield of different crosses were $\mathrm{P}_{1} \times \mathrm{P}_{8}$ (66.93), $\mathrm{P}_{5} \times \mathrm{P}_{8}$ (54.83), $\mathrm{P}_{5} \mathrm{x}$ $\mathrm{P}_{9}$ (52.17), $\mathrm{P}_{1} \times \mathrm{P}_{5}$ (44.64), $\mathrm{P}_{7} \times \mathrm{P}_{8}$ (43.78), $\mathrm{P}_{4} \times \mathrm{P}_{10}$ (38.31), $\mathrm{P}_{1} \times \mathrm{P}_{2}$ (37.61) and $\mathrm{P}_{4} \times \mathrm{P}_{9}$ (35.63). Out of these, cross, $\mathrm{P}_{1} \times \mathrm{P}_{8}$ also showed the positive significant per cent heterosis for ear length and 100-kernel weight and good per se performance of other remaining traits, therefore, this cross, is classified as best from practical point of view. Vivek et al. (2009) and Snezana et al. (2012) also reported the significant standard heterosis for grain yield, while Shete et al. (2011) and Aminu et al. (2014) also reported the significant standard heterosis for grain yield along with ear length, no. of kernels per row and 100-kernel weight, and recommended the heterosis breeding for crop improvement programme

\section{Conclusion}

Heterosis breeding is suggested for the development of effective cultivars of maize crop because of the presence of more amount of variance due to SCA effects than GCA effects. Good general combiner parents along with high per se performance were $\mathrm{P}_{1}$ and $\mathrm{P}_{4}$ for ear length; $\mathrm{P}_{8}$ for number of kernel rows per ear; $\mathrm{P}_{4}$ for number of kernels per row and $\mathrm{P}_{9}$ for100-kernel weight, which, can be utilized as donor as yield attributing traits in crop improvement programme. However, $\mathrm{P}_{8}$ for ear diameter and $\mathrm{P}_{5}$ for grain yield were 
having the good GCA effects along with low per se value, therefore, could not be classified as good parental lines. The crosses, $\mathrm{P}_{1} \times \mathrm{P}_{2}, \mathrm{P}_{1} \times \mathrm{P}_{8}, \mathrm{P}_{4} \times \mathrm{P}_{9}$ and $\mathrm{P}_{7} \times \mathrm{P}_{8}$ manifested high SCA effects along with excellent standard heterosis and per se performance for grain yield and also for most of the studied characters, therefore, classified as potential hybrids for commercial purpose.

\section{REFERENCES}

Alam, A.K.M.M, Ahmed, S., Begum, M. and Wali, M.C. (2008). Heterosis and Combining ability for grain yield and its contributing characters in maize. Bangladesh $J$. Agril. Res. 33(3): 375-379.

Alamine, A., Nayankar, N.Y. and Wali, M.C. (2003). Combining ability, heterosis and per se performance of height characters in maize. Karnataka J. Agric. Sci. 16 (1): 131-133.

All India Coordination Research Project (AICRP) on Maize, (2015). 58th Annual Report by Directorate of Maize Research, Indian Council of Agriculture Research (ICAR), Pusa, New Delhi, held at PAU, Ludhiana April 4-6.

Aminu, D., Mohammed, S.G. and Kabir, B.G. (2014). Estimates of combining ability and heterosis for yield and yield traits in maize population (Zea mays L.), under drought conditions in the Northern Guinea and Sudan Savanna zones of Bornostate, Nigeria. IJAIR. 2(5):824-830.

Amiruzzaman, M., Islam, M.A., Hassan, L. and Rohman, M.M. (2010). Combining ability and heterosis for yield and component characters in Maize. Academic J. Plant Sci. 3(2): 79-84.

Elmyhum, M. (2013). Estimation of combining ability and heterosis of quality protein maize inbred lines. African J. Agril. Res. 8(48): 6309-6317.

Griffing, B. (1956). Concept of general and specific combining ability in relation to diallel crossing systems. Aust. J. Biol. Sci. 9: 463-493.
Guerrero, C.G., Miguel, A.G.R., Jose, G.L.O., Ignacio, O.C., Cirilo, V.V., Mario, G.C., Alejandro, M.R. and Anselmo, G.T. (2014). Combining ability and heterosis in corn breeding lines to forage and grain. American $J$. Pl. Sci. 5:845-856.

Haddadi, M.H., Eesmaeilof, M., Choukan, R and Rameeh, V. (2012). Combining ability analysis of days to silking, plant height, yield components and kernel yield in maize breeding lines.Afr. J. Agric. Res. 7(33): 4685-4691.

Kambe, G.R., Kage, U., Lohithaswa, H.C., Shekara, B.G. and Shobha, D. (2013). Combining ability studies in maize (Zea mays L.). Mol. Pl. Breed. 3(14):116-127.

Kumar, M. Singh, R. and Srivastava, R.P. (2015). Screening genotypes for maize (Zea mays L.) for Eastern Uttar Pradesh conditions. International Journal of Applied Agricultural \& Horticultural Sciences. 6(2): 237-240.

Rokadia, P. and Kaushik, S.K. (2005). Exploitation of combining ability for heterosis in maize (Zea mays L.). In: Pixley, K. and S.H. Zhang (ed). Proc. 9th Asian Reg.Maize Workshop. Beijing, China, September 5-9, pp: 89-91.

Shete, J.M., Patel, M.P., Gami, R.A. and Patel, C.G. (2011). Study of heterosis in top cross derivatives of Maize (Zea mays L.). Agric. Sci. Digest. 31(1): 1-7.I

Singh, R.K. and P.K. Singh, (1994). A manual on Genetics and Plant Breeding. Experimental Techniques. Kalyani Publs, Ludhiana, New Delhi, pp: 99-107.

Snezana, M.D., Marija, K., Danijela, R., Milan, S., Zoran, C., Milomir, F. and Dragan, K. (2012). Correlation of yield and heterosis of maize hybrids and their parental lines with genetic distance based on SSR markers. Genetika. 44(2): 399-408.

Vivek, B.S., Crossa, J. and Alvarado, G. (2009). Heterosis and combining ability among CIMMYTs mid-altitude early to intermediate maturing maize (Zea mays L.) populations. Maydica. 54: 